\title{
The Relationship Between Gratitude and Social Support with The Stress of Mother Who Have Children in Special Needs
}

\author{
Mega Rista Saras Ati*)1, Andik Matulessy², Muhammad Farid ${ }^{2}$ \\ ${ }^{1}$ Alumni Fakultas Psikologi Universitas 17 Agustus 1945, Surabaya \\ ${ }^{2}$ Staff Pengajar Fakultas Psikologi Universitas 17 Agustus 1945, Surabaya \\ ${ }^{3}$ Staff Pengajar Fakultas Psikologi Universitas Darul Ulum, Jombang \\ "Corresponding author: mgarista86@gmail.com
}

\begin{abstract}
The purpose of this research is to know the relation between gratitude and social support with the stress of mother s who have children in special need. Through random sampling techniques, acquired the subject 30 mother s who have children in special need in Surabaya. This research is the gauge scale gratitude scale, stress and social support scale. Research data were analyzed with regression shows double $\mathrm{F}=4.750$ and $\mathrm{sig}=0.01$ means there is a significant relationship between social support and gratitude with the stress of mother $\mathrm{s}$ who have children in special need. The results of the $\mathrm{R}$ square $=0.260$ meaning stress mother $\mathrm{s}$ who have children in special need can be explained by the gratitude and social support of $26 \%$. Next partially gratitude does not correlate with the stress mother $\mathrm{s}$ of children in special need (partial $\mathrm{r}=0.001$ with sig $=0.998)$, and social support proved to be significantly correlated negatively with the stress mother of children in special needr partial $=-0.480$ with sig $=0.008$
\end{abstract}

Keyword: Gratitude, social support, stress, and children in special needs.

\begin{abstract}
Abstrak. Tujuan riset ini adalah mengetahui hubungan antara kebersyukuran dan dukungan sosial dengan stres orang tua yang mempunyai anak berkebutuhan khusus. Melalui teknik random sampling, diperoleh subjek penelitian 30 orang tua yang memiliki anak berkebutuhan khusus di Surabaya. Alat ukur penelitian ini adalah skala stres, skala kebersyukuran dan skala dukungan sosial. Data penelitian dianalisis dengan regresi ganda menunjukkan $\mathrm{F}=4,750$ dan sig $=0,017$ berarti ada hubungan signifikan antara kebersyukuran dan dukungan sosial dengan stres orang tua yang memiliki anak berkebutuhan khusus. Hasil $\mathrm{R}$ square $=0,260$ yang berarti stres orangtua yang memiliki anak berkebutuhan khusus dapat dijelaskan oleh kebersyukuran dan dukungan sosial sebesar $26 \%$. Selanjutnya secara parsial kebersykuran tidak berkorelasi dengan stres orangtua anak berkebutuhan khusus ( $\mathrm{r}$ parsial $=0,001$ dengan sig $=0,998$ ), dan dukungan sosial terbukti signifikan berkorelasi negatif dengan stres orangtua anak berkebutuhan khusus $\mathrm{r}$ parsial $=-0,480$ dengan $\operatorname{sig}=0,008$.
\end{abstract}

Katakunci: Kebersyukuran, dukungan sosial, stres, anak berkebutuhan khusus 


\section{Introduction}

The presence of the first child is the beginning of happiness as a parent, because household chores will be growing, takes time and attention to the care of the child, as well as reducing the time to rest. The child who was born perfect was the hope of all parents. Mother crave to have healthy children, both physically and spiritually. Not all children are born and grow up in a normal state. Some children have limitations either in physical or psychic, experienced since the beginning of the period of development. Children in special need child that deviate from the average normal children in the case; characteristics of mental, sensory abilities, physical and neuro mascular, social and emotional behavior, ability to communicate, as well as a combination of two or more of the above matters; so far as it requires the modification of school assignments, learning methods or other related services, aimed at developing the potential or capacity to the maximum. The presence of a child in the family is a fun thing, when a children in special need, originally a parent usually surprised, disappointed the weight, stress, anger, frustration, not even a little bit of denial. The time when the mother are thoughtful and not knowing what to do next, not least also a parent not open about the State of his son to the surrounding environment except the doctor dealing with the child. The problem in terms of one's child sufferers family who suffers from developmental abnormalities can be a burden for mother (Mira, 2013). More time and attention should be given to the child. The role of mother is huge in impact the lives of a child, especially in the early stages as well as the critical stage, when the mother are not able to manage emotions properly, it is not possible as a result imposes on the children. In addition to medical assistance in therapy the children in need is also needed, resting on the importance of the support of parents.

Children in special need is the child who has its own uniqueness in types and their characteristics, distinguishing it from normal children generally. Experiencing delays and interruptions in its development so that requires special handling. Children in special need usually attended the extraordinary in all schools (SLB) but in Surabaya, there are schools in the elementary school (SDN) which received children in special need and mixing them with regular students, except they are indeed true severe is suggested to the SLB for further handling. Children with special characteristics which are different with a child on the common facilities without always showing the inability of the mental, emotional, or physical, which included into special needs children are: blind, deaf, mental retardation, limb defect, unsociable, learning difficulties, slow learning, behavioural disorders, children are gifted and children with health disorders, autism and ADHD (Attention Deficit Hyperactive Disorder).

Load trigger stress on mother (parenting stress) that have a negative impact on older people, the relationship of mother - children, and children themselves. The excess anxiety and specifically related to the existence of a relationship between mother and children. Psychosocial issues faced by mother in particular by mom: mourning, despair, anxiety, stress, depression, powerlessness, and body image disorders. According to research from Rangaswamy and Bhavani (2008) level of stress of mother who have disabled children may be higher compared to normal children. Overall, it appears that positive social support high 
quality can increase resistance to stress, helps protect against developing psychopathology related to trauma in having children (Southwick, 2005).

Stress is the situation that emerged in the aftermath of various aspects of life included in the parenting process. Parenting children who experience against obstacles, for example intellectual barriers often gave rise to difficulties for mother because the children who experienced the intellectual disability (hereinafter abbreviated ID) have limitations that significantly from the intellectual and adaptive behavior function, among others, the ability of the conceptual, social and practical skills (American Association on Intellectual and Developmental Disabilities, 2010).Care given to children in special needcause stress, caused by a problem in the care economy in need of a special other than children (Schieve 2007).Experience stress from time to time on their own psychological problems, such as depression, anxiety, mood disorders, and other mental health issues (Bryant, 2010).Every parent facing the diagnosis for her son definitely showed a strong emotional reaction, as this is a very difficult issue for mother and forced to accepted. Different behavior shown heavier than a child her age. The old man was someone close to the child where there is a family member like father, mother and children are the result of their marriage. One of the factors forming individual family is getting the descendants or children. In addition to that another factor is to meet the needs of biological and for the Division of tasks such as educating children, earn a living and so on. Stress is not helpless when someone gives negative response in him. Mother who have children in special need, the negative effects of cognitively, among others, has always had a negative thought patterns, anxiety in taking care of children, sick with diarrhea, fatigue while taking care of children, anger - anger, irritability, lack of appetite for eat, shortness of breath, and smoking (Aurora, 2008).

The word "stress" could be interpreted differently for each individual. Stress is a feeling felt by someone if it accepts the demands. Demands received could be come in the form of the existence of the fulfillment of the expectations of the family and for academic achievement (Syahabuddin degree, 2010). According to the American Psychological Association, 2012 about the stress the following symptoms are commonly perceived stress sufferers cognitive symptoms, symptoms include emotional, and behavioral symptoms. The impact of stress is reduced by means of creating a supportive environment. The support of family and friends will create a pleasant atmosphere. Social support according to Johson and Johson (Taifur, 2003) is the influence of surrounding where can to give a contribution, suggestion and acceptance where such person has a conflict in his life. Social support from the environment around will give a positive influence for the individual. Sarason (Taifur, 2003) found that individuals who had more social support will have a more self-esteem and self-concept, there are limitations they have optimistic view towards life.

Mother feel grateful for the grant of their children with disabilities will always dote-with vengeance. Gratitude is the factor that encompasses some of the situations and events that give rise to an impersonal source e.g. in nature and nonhuman beings such as gods and animals (Emmons \& McCullough, 2003; McCullough, Emmons \& Tsang, 2002; Wood et al., 2010).Gratitude associated with positive emotions and subjective (Wood, 2010) and psychological well-being 
(Wood, Joseph \& Maltby, 2009).Life cycle developed by Erikson's eight stages of development there, in pursuit of the ideal State should pass through the stages of a crisis of integrity with despair. According to the research of McAdams and Bauer (2004) said that the challenges of the end of human life the most-high is thankful, this behavior would make someone who lived through it all these years will be blessed. Religious context also became the focus of where the mother are grateful for being able to acquire meaning, purpose, and coherence in their life. Research on Gratitude is a relatively new topic such as how individuals strengthen their social networks, satisfied over the life lived, it brings happiness, and appreciated the positive results in life (Wood, Froh was, \& Geraghty, 2010).

The problems experienced by mother who have children in special need child behavior problems, such as the ability of the child, the issue of the necessary costs, education and therapy, as well as the issue of relations with other family members or lack of social support is causing stress (Ginanjar, 2002). Load trigger stress on mother (parenting stress) that have a negative impact on older people, the relationship of mother - children, and children themselves. Psychosocial issues faced by mother in particular by mom: mourning, despair, anxiety, stress, depression, powerlessness, and body image disorders. Care given to children in special needcause stress, caused by a problem in the care economy in need of a special other than children (Schieve 2007). Stress most often appeared and obtained by mother is how mother can fulfill the wishes of children in need in their everyday activity dependence (Lopez et al., 2008).

The facts presented above, which describes the stress that has been tailored to families who have children with developmental impediments. Great care needed by children with limitations in the long term or long impact on Psychology health of the elderly (Seltzer et al,2009). Signs of stress in the elderly will detract response and sensitivity to cues the child, can make things worse and interfere with the therapeutic results of the child by the child (Swartz, 2005). Stress is an aspect which cannot be avoided by individuals. Stress can be experienced by anyone and have negative implications if it accumulates in the lives of individuals without the right solution. The accumulation of stress is a result of the inability of an individual in overcoming and controlling stress (Crampton, Hodge \& Mishra, 1995). Stress, optimal will result in challenges and the motivation to go forward for individuals (Spangenberg \& Theron, 1998).

Someone who has a sense of being grateful is the individual can be a blessing, honor and respect how the value of the gift. Individuals who are grateful as if someone was able to identify private conscious and know how to pronounce the gratitude of God's grace, the support of other people, and have given time for the overflow of gratitude. Feel grateful to have much of a positive impact both in terms of emotional, physical and interpersonal (Emmons \& McCullough, 2003). People who have a sense of gratitude is high tend to have high levels of positive emotions and negative emotions levels are low as anxiety, envy (McCullough et al, 2002), the levels of stress and depression are low (McCullough et al, 2004). Work environment, feeling grateful to bring positive impact both for the individual and the organization. The perceived positive emotions of the individual that will encourage an increase in the quality of an individual in the organization.

According to Emmons \& McCullough, 2004 words of gratitude is a word taken from the Latin gratia meaning i.e. softness and thank you. The Latin word is 
associated with the kindness, generosity, the beauty of giving and receiving, or get one with no purpose whatsoever. The above statement may imply that Gratitude is feeling happy someone who appeared in need of something, receive the gift and that person would be sure already feel is excessive. Gratitude or Gratitude can be considered as three things, that emotion, virtue, and trait. Gratitude is seen as a power that involves people to feel gratitude (McCollugh, Emmons et al, 2002).

Some of the factors in the Gratitude according to Fitzgerald, 1998 namely: the taste of a warm appreciation for others or which includes feelings of love and affection, good intentions and is given to a person includes a desire to help others, and positive attitude to act based on a sense of appreciation and good will, including often help others as well as the reply of kindness with kindness. Other researchers assume that abundance, respect for others, and an appreciation for the simple things. Gratitude generally describes the attitude of appreciation of life and all the positive things that exist the around. Three characters on the individual who always thankful that is abundance, respect for others, and an appreciation for the simple things (Emmons; Roberts; Tesser; Gatewood; and drivers; Tsang; Watskin, Scheer, Ovnicek, and Konig in the Kolts and Glück; 2013).

Face of a child in need of a stressful situation-specific, a person in need of social support. States that social support refers to give comfort to other people, take care of him or appreciate it. Social support may take the form of granting information, help with behavior, or material that is obtained from the familiar social relationships that can make individuals feel cared for, valued, and loved. In addition social support is the perception of the individual who the giving something to others in their social networks (e.g., spouse, family and friends) which helps improve the ability to defend yourself from influences that detrimental. Social support includes emotional, information, material or tools provided. The appearance of the existing social support will improve the selfesteem and self-control than someone (Cohen and Syme, 1985) so that it can bring up the nature of the social needs in improving caregiving from mother of children in special need. When social support occurs can prevent the occurrence of stress.

Factor of family social support according to the House and Khar (1985) as follows:

1. Emotional support: include empathy, concern for the person concerned for example feedback or suggestion made by others.

2. Support award: takes place when the statement is disinclined (tribute) positive for that person, forward or urge like-minded thought or opinion of the individual and the equality of man was positive with other people, such as people who are not able to or be worse case (adds to the prestige or dignity).

3. Instrumental support: includes the granting of such a person gives money to the aid or help someone with the same circumstances.

4. Informative Support: includes the granting of mandate, instructions, opinions or proposals.

The explanation above it can be concluded that Gratitude or gratitude one can note the impact of the grateful feelings can develop into a reaction or response takes the form of an attitude. Therefore, gratitude can encourage or motivate someone to give in return for the granting or the kindness of others have done 
(Smit; Weiner \& Graham; McCullough \& Tsang, 2004). While social support with the stress that where stress is feeling threatened is accompanied with an attempt resolve to reduce the sense of existence threatened by social support from family or couples can reduce the stress by means of existence the involvement of others with us in dealing with a problem. Lowering stress can be controlled by how someone get social support from someone who is there around the (Rozanski, 1999). The higher the social support and the Gratitude of mother who have children in special need will reduce stress because of support from the husband in the parenting will effect if custody is just grateful the lack of support received. Vice versa if a person's social support low physiological and reactivity of high stress will increase the heart rate and respond to excessive neuroendocrine cardiovascular (Uchino et al., 1999).

The hypothesis made by researchers, namely:

1. There is a relationship between social support and gratitude with the stress of mother who have children in need special

2. There is a negative relationship between social support with stress against mother who have children in need special

3. There is a negative relationship between gratitude with stress against mother who have children in need special

\section{Methods}

\section{Participant}

The population in this research is the public Surabaya, a mother has the children in special needs with various disability in elementary school area II Surabaya include SDN Kalirungkut I, SDN Kutisari I, SDN Klampis Ngasem II, SDN Klampis Ngasem I, SDN Sutorejo, SDN Menur Pumpungan SDN SDN Pacar KelingIX, SDN Gununganyar I and SDN Tambasari III. The school selected by the researchers of the existing schools in the area occurring East and public schools designated by the government of the city of Surabaya to hold school inclusion. The researchers chose a mother because child born has a stickiness (attachment) on a mom where at the time the child can help social competence and social welfare of teens (Santrock, 2007), seen from the high selfesteem, have emotional adjustment, and physical health. Individuals who experience a secure attachment is the individual who always believes that he is loved and appreciated by others and gets full attention, judging the figure latched onto as a responsive, caring and trustworthy, feel comfortable if in a closeness or intimacy, always being so optimistic and confident, and able to foster close relationships with other people (Collins and Feeney, 2004). The sample in this research is a part of the population. Total sample consisted of 30 people aged around 20 years to 50 years. Sample criteria specified about 20 years to 50 years is based on the consideration that the individuals in the age group have a similar developmental tasks, namely, developing and maintaining skills are closely related to the interests of career development and foster household. Erikson (Santrock, 2002) says that the crisis at the age of 20 to 40 years old who belong to the period of early adulthood, will occur when the individual is trying to build 
closeness. Individuals on the adult stages of development the early start to make decisions related to social relationships, career, and lifestyle. The average age of mother s who were taken by the respondents is $26-31$ years. An important task of the individual adult beginning is resolving conflicts associated proximity, competition, and social distance. Individuals with mature personality, has a condition that is ready to create the social closeness. The data was collected using the observation technique, interviews and give the question form where the data will be processed into a data source. Self-reports of parties examined (the respondent) regarding the stress of mother who have children in need special.

The data can later be used as the basis of an analysis of previous research processed and interpreted, then the existence of a comparative theory exists with its implementation, so that researchers can be suggested how unresolved objects already researched. The data retrieved is the empirical data that has certain valid criteria. Descriptive method used in this research to describe or analyze a research results. Research objectives categorized analysis, i.e., descriptive research methods that describe or explain the nature of the data which is actual and continued by analyzing the search for a relationship, connection and influence between specific variables with other variables.

\section{Measure}

Variable depends in this research was stressed. Free variables in this study are gratitude and social support. Experimental study of using quantitative approach by using the scale as a means of collecting the data. The scale is used there are three, i.e. the scale gratitude and social support. Test result reliability Alpha coefficient obtained stress scale reliability of test result reliability, 0.931 Alpha scale gratitude retrieved reliability of 0926, and reliability test results of the Alpha scale of social support obtained reliability of 0.844. (Adler and Fegley; Lambert et al; Wood, Froh Was, Geraghty; Wood, Matlby, Stewart, and Joseph in Koig and Glück; 2013) explains each aspect of abundance, respect for others, and an appreciation for the simple things and the social support scale has been said House, (Smet, 1994) explains each aspect that includes: the instrumental support (the existence of School inclusion provides an opportunity for my child can learn with friends), emotional support (I feel accepted family surroundings spouses childbirth in need special),, support award (husband/wife I appreciate every action that I have done for the good of our children) and support informative (the couple can be a source of information about what should I do on my children). Aitem stress on a scale that was given to the respondent based on the aspect of cognitive symptoms (I hardly concentrate on work, so many make a mistake), emotional (irritability when I see other people do mistake), behavioural ( I rarely provides time off for a vacation with the family), and physiological (I am prone to flu when it was a lot of work).Scale based on gratitude aspects, namely an abundance (I don't mind if there are people who ask for time off because I have a lot of time), a tribute to someone else (I often convey a thank you via written messages such as SMS, Whatsapp, Email, Line, etc.), and an appreciation for the simple things (I make use of free time with the family gathered together). The focus of research by using the mother who have children in need with a variety of disability. 


\section{Analysis}

Technique of data analysis used in this study is double regression analysis to test the hypotheses of relationships, social support gratitude with stress.

1. Double regression analysis results obtained significant relationship exists between gratitude and social support with the stress of mother who have children in need special. Results of this research indicate that there is a research hypothesis the relationship between social support and gratitude with the stress of mother who have a child in need of proven special.

2. Partial correlation obtained results means there is a very significant negative correlations between social support with the stress of mother who have children in special needs by controlling the variable gratitude. This means that the higher the social support received will be the lower stress of mother who have children in need special, and vice versa. The findings of this research suggests the hypothesis that there is a negative relationship between social support with the stress of mother who have children in need special.

3. partial correlation obtained Results there is no negative correlation between gratitude with stress to mother who have children in special needs social support variable control. The findings of this research suggests the hypothesis that there is a negative relationship between gratitude with the stress of mother who have children in special needs rejected.

4. Multiple regression test calculation results obtained $R^{2}$ (R Square) for 0.260 or (26\%). This shows that the percentage of contribution to the influence of gratitude and social support to stress amounted to $26 \%$ while the rest $74 \%$ stress a parent who has a child in need of specially affected by other variables.

\section{Findings}

\section{Characteristic}

Variable depends in this research was stressed. Stress is the individual cognitive assessment process continues on the perception that there is a requirement of the environment that cannot be controlled because it exceeds his ability to meet these demands and felt burdensome, thus leading to the effect negative and threatening the well-being. As for the stress symptoms are generally grouped into four major parts, namely cognitive symptoms, symptoms of emotional, behavioral, physiological symptoms. Test process for measuring instrument using SPSS program version 24, where the results of this analysis indicate that the reliability coefficient scale stress has exceeded the minimum reliability coefficient 0.700 . Reliability coefficient of stress scale 0.931 meaning differences (variations) that looks at stress scale score is capable of reflecting $93.10 \%$ of the variations that occur in the pure subject Group score is concerned, and $6.90 \%$ difference score that looks caused by the variation of the measurement errors.

Social support is a source of emotional, information or facilitation provided by those around the individual to deal with any problems and crises that occur in life. Social support consists of information or advice is verbal or nonverbal, real help or action taken due to the presence of other people and have the 
benefits of emotional or behavioral effects. Three characters on the individuals who get social support is support emotional, support information, support instruments, and a positive assessment on others.

Test result reliability Alpha coefficient obtained social support scale reliability of 0.844 analysis results reliability coefficient indicates that the scale of social support have exceeded the minimum reliability coefficient 0.700 .Reliability coefficient of social support scale 0.844 meaning differences (variations) that looks at stress scale score is capable of reflecting $84.4 \%$ of the variations that occur in the pure subject Group score is concerned, and $15.6 \%$ of the difference score that seemed to be caused by variations in measurement error. The process of computing power of discrimination testing grain and test reliability measuring instrument research using SPSS program version 24 contained in attachment generates data social support scale consists of 82 rounds. After a test power of discrimination grains showed 46 eligible grain power index discrimination and 36 rounds. The details that otherwise meet the power of discrimination coefficient, grain grains with a score total corrected scale ranges 0.250 up to 0.907 .

Gratitude is a condition associated cognitive presence of affection towards the perceptions of personal benefit that is not deliberately sought or obtained, and the introduction of the back that the source of all goodness comes from outside yourself. As for the three characters on the individual who always thankful that is abundance, respect for others, and an appreciation for the simple things.

Test result reliability Alpha coefficient obtained reliability gratitude scale amounting to 0.926 .The results of this analysis indicate that the reliability of the scale coefficient gratitude have exceeded the minimum reliability coefficient 0.700.Gratitudescale of reliability coefficient 0.926 meaning differences (variations) that looks at this gratitude able to scale score reflecting $92.60 \%$ of the variations that occur in the pure subject Group score is concerned, and $7.4 \%$ difference score seem caused by the variation of the measurement errors.

The process of computing power of discrimination testing grain and test measuring instrument research using SPSS program version data that has produced 24 Scale Gratitude composed 76 grains. After a test power of discrimination, shows 63 grains of grains eligible power index discrimination and 13 grains fall. The details that otherwise meet the power of discrimination coefficient of correlation, grain grains with a score total corrected scale ranges from 0.250 to 0.716 .

The dual regression analysis results obtained $\mathrm{F}=4.750$ with $\operatorname{sig}=0.017(\mathrm{p}$ $<0.05$ ) means there is a significant relationship between social support and gratitude with the stress of mother who have children in need special. Partial correlation obtained results- 0.480 with sig $=0.008(\mathrm{p}<0.01)$ means there is a very significant negative correlations between social support with the stress of mother who have children in special needs control variables gratitude.

Partial correlation of results obtained with $0.001 \mathrm{sig}=0.998(\mathrm{p} 0.05>$ ) means no negative correlation between gratitude with stress to mother who have children in special needs when social support variables by controlling.

\section{Correlation}


The dual regression analysis techniques in this study to examine the existing data which test the hypothesis gratitude relationship, social support with the stress of mother who have children in need special. Test assumptions used is variable depending on the distribution normality test with variable stress distribution rule stated is normal if $p>0.05$. The results of the calculation technique of normality distribution obtained Kolmogorov-Smirnov $\mathrm{Z}$ on gratitude of 0.130 and sig $=0.200(p>0.05)$, social support of 0.155 and $\operatorname{sig}=0.065(>p$ $0.05)$, and the stress of 0.95 and sig $=0.200(\mathrm{p}>0.05)$. Population distribution data obtained above is the data with a normal distribution. While the test liniearity the relationship between social support variables and variable gratitude variable against stress with rule liniearity relationship of the test using the quantity deviation from liniearity with prices $p>0.05$. Liniearity test results showed that all the variables are free, i.e. variables gratitude and correlation social support variables with linear variable depending on stress, as summarized in table 1.

Tabel 1. Hasil uji linieritas

\begin{tabular}{lllll}
\hline & Variabel & F & P & Status \\
\hline \multirow{2}{*}{ Stres } & Dukungan Sosial dan & 0,907 & 0,622 & Linier \\
& Gratitude dan Stres & 9,722 & 0,249 & Linier \\
\hline
\end{tabular}

Test multi-coliniearity relations between fellow non multi-coliniearity Testing variables was conducted to know the linear correlation that is approaching the perfect or perfectly among the variables in the regression analysis models. How to test used for multi-coliniearity is:

1. Compare the values of Tolerance and the value of the VIF (variant of the Inflation Factor) value Tolerance $>0.30$ and VIF $>0.90$ means not found the presence of multi-coliniearity. The results of the analysis of the data shows no found the existence of the multi-coliniearity, as summarized in table 1.

2. Considering the large coefficient of correlation between the variable free. Relationships between variables are free multi-coliniearity will occur if the free variables of fellow correlations greater than 0.800 data research shows that is not the case when the multi-coliniearity correlation variable fellow non less than 0.900 .

The dual regression analysis results obtained $\mathrm{F}=4.750$ with sig $=0.017(\mathrm{p}$ $<0.05)$ means there is a significant relationship between social support and gratitude with the stress of mother who have children in need special. Results of this research indicate that there is a research hypothesis the relationship between social support and gratitude with the stress of mother who have children in need special. Partial correlation obtained results- 0.480 with sig $=0.008(\mathrm{p}<0.01)$ means there is a very significant negative correlations between social support with the stress of mother who have children in special needs by controlling the variable gratitude. This means that the higher the social support received will be the lower stress of mother who have children in need special, and vice versa. The findings of this research suggests the hypothesis that there is a negative relationship between social support with the stress of mother who have children in need 
special. Partial correlation of results obtained with $0.001 \mathrm{sig}=0.998(\mathrm{p} 0.05>)$ means no negative correlation between the gratitude with the stress of mother who have children in special needs social support variable control. The findings of this research suggests the hypothesis that there is a negative relationship between gratitude with the stress of mother who have children in need special. Multiple regression test calculation results obtained R2 (R Square) for 0.260 or (26\%). This shows that the percentage of contribution to the influence of gratitude and social support to stress amounted to $26 \%$ while the rest $74 \%$ stress a parent who has a child in need of specially affected by other variables.

\section{Discussion}

The results of this study using double regression analysis and found that gratitude and social support variables together effect on stress. Related stress factors examined in this study are gratitude and social support thus formulated three hypothesis regarding the relatedness of a third variable. The first hypothesis is there a relationship between gratitude and social support to stress of mother who have children in need special, the higher the second variable that can reduce the stress of mother who have children in need special. Research McCullough et al. (2002) explains that having a great gratitude to something and social support in relationship with others will reduce the stress caused. If only a high gratitude can't decrease the stress because there is no social support from family or couples, and gratitude a balanced way can reduce the stress of mother who have children in special needs(Watkins, Uhder, \& Pichinevskiy, 2014).

The second hypothesis is there a positive relationship between social support with the stress of mother who have children in need special, the higher the social support then the lower stress. Social support is the interpersonal relationships that can anticipate the onset of stress. If someone is getting social support when problems arise can pass well because other people can provide a solution or input, even if not given the least we've tried to express something to someone else.

The third hypothesis is a positive relationship between gratitude with the stress of mother who have children in need special, the lower gratitude then the higher the stress that is owned by a parent. Gratitude is a form of emotions or feelings which then evolved into an attitude, good moral nature, habits, personality traits, and ultimately will affect a person's response to/in action against something or a situation.

Social support can reduce the stress of mother $s$ who have children in special needs because not only do they give thanks to the creator but their parenting with as best as possible and supported by partner in caregiving both emotional support ( the existence of feedback given by the couple about parenting), Awards (give a prize to the wife because of parenting every day by referring the holiday), instrumental (the couple gave money as support for meet the needs of the children require the funds to do the therapy), and informative (the 
couple gives information about what may be the result of getting information for the sustainability of their children).

This study has been organized and carried out in accordance with the scientific procedure, however still has its limitations, namely lack of subjects in research at a minimum so that the lack of information obtained and has more time to do anamnesa through home visits - home.

\section{Conclusion and Recommendation}

\section{Conclusion}

Based on the results of the research there is the first hypothesis about the relationship between gratitude and social support to stress of mother who have children in special needs has been tested in this study. Based on the results of the calculation of the SPSS version 24.00 with regression analysis techniques provided on attachment obtained significance levels below 0.05 ie 0.00 so that it can be concluded that gratitude and social support variables simultaneously effect on stress.

The second hypothesis there is a negative relationship between gratitude and stress, the lower gratitude the higher level of stress to mother who have children in need special. Gratitude in the absence of social support can't lower the stress, because social support from partner foster a sense appreciated, cherished, and get information from the partner. Research of Wood, et al 2007 shows that the gratitude effect on the high perception of social support.

The third hypothesis there is a negative relationship between social support and stress, the higher the social support then the lower stress. The results of these studies showed a relationship between variable may social support and stress variables, so the third hypothesis tested in this study. More specific social support variables proved to have the opposite direction relationship variable with stress, this means that any reduction in the value of social support one valueadding the stress of 0.510. The existence of positive interest between social support and stress in this research as well as in research conducted by Smet (1994) between the gratitude and the gratitude, the lower the stress then the higher stress.

The relationship between gratitude and social support with the stress of mother who have children in special needs can deduce that there is a very significant negative correlations between social support with the stress of mother who have children in special needby controlling the variable gratitude. This means that the higher the social support received will be the lower stress of mother who have children in need special, and vice versa. Where as there is no negative correlation between the gratitude with the stress of mother who have children in special needs social support variable control. The possibility that appeared more than $74 \%$ by other factors.

\section{Recommendation}

Based on the results of research and discussion as described above, then it can put forward suggestions as follows:

1. For The People That Have Children In special need 
Communities that are experiencing stress in dealing with children in need of special assistance can request information about the children in need special to the psychologist that exist in every public school in the region I-V in the city of Surabaya and clinics that already exists psychology or psychologists. The Government is already planning how to make Surabaya appropriate action in with dealing.

2. For Couples

The results of the research of very large very influential partner in supporting good parenting to help in support of action or conduct, physical, and exchange opinions. Further increase with the presence of communication in family and attention to couples very mean in caregiving

3. For researchers

For researchers, it is expected to be able to do the research again related to parents who have children in need special deeper again so that information collected becomes a lot more by using anamnesa /interviews, expanding again information about the gratitude, as well as looking for more so other factors in the study next.

\section{References}

American Association on Intellectual and Developmental Disabilities. (2010). Frequently Asked Questions on The AAIDD 11 th Edition of Intellectual Disability: Definiton, Classification, and Systems of Supports. Washington: The AAIDD Terminology and Classification Committee.

American Psycological Association. (2012). Stres in America : Our Health at Risk. American Psychological Association.

Bryant, R. (2010). Treating the full range of post traumatic reactions. In Rosen, G. \& Frueh, B. (eds), Clinician's Guide to Post traumatic Stress Disorder,. Hoboken, NJ: John Wiley \& Sons

Cohen, S. and Syme S.L. (1985). Social Support. Academic Press, INC. London Collins and Feeney. (2004).Working Models of Attachment Shape Perceptions of Social Support: Evidence From Experimental and Observational Studies. Journal of Personality and Social Psychology. 87(3), 363-38.

Crampton, S.M., Hodge, J.W., \& Mishra, J.M.. (1995). Stress and Stress Management. Journal of Advance Management. 60(3), 10

Emmons, R. A., \& McCullough, M. E. (2003). Counting Blessings Versus Burdens: An Experimental Investigation of Gratitude and Subjective Well-Being in Daily Life. Journal of Personality and sosial Psychology, 84, 377-389. doi: 10.1037/0022-3514.84.2.377

Fitzgerald. (1998). Gratitude and Justice. Ethics, 109 (1), 119-153

House, James S. and Robert L. Kabarl . (1985). Measures and concepts of social support. In Sheldon Cohen and S Leonard Syme (eds.), Social Support and Health: 83-108. New York: Academic Press

König, S., \& Glück, J. (2013). "Gratitude is with me all the time:: how gratitude relates to wisdom. Journal of Gerontology. Series B: Psychological Sciences and Social Sciences. 
Lopez, V., Clifford, T., Minnes, P. and Ouellette-Kuntz, H., (2008) Parental stress and coping in families of children with and without developmental delays. J. Devl. Disabilities., 14(4), 99-103.

McAdams, Dan P. and Jack J. Bauer. (2004). "Gratitude in Modern Life: Its Manifestations and Development." Pp. 81-99 in The Psychology of Gratitude, edited by Robert A. Emmons and Michael E. McCullough. New York: Oxford University Press.

Mc Cullough, M. E., Emmons, R. A., \& Tsang, J. A. (2002). The grateful disposition: A conceptual and empirical topography. Journal of Personality and Social Psychology, 82, (1), 112-127.

McCullough, M. E., Tsang, J. A., Emmons, R. A. (2004). Gratitude in Intermediate Affective Terrain: Links of Grateful Moods to Individual Differences and Daily Emotional Experience. Journal of Personality and Social Psychology, 86 (2), 295-309. The American Psychological Association, Inc.

Mira, Destryarini. (2013). Strategi Coping dan Kelelahan Emosional (Emotional Exhaustion) pada Ibu yang Memiliki Anak Berkebutuhan Khusus (Studi Kasus di Rumah Sakit Jiwa Daerah Atma Husada Mahakam Samarinda, Kalimantan Timur). eJournal Psikologi. 1(2), 123-135.

Pruyser, P. W. (1976). The minister asdiagnostician: Personal problems in pastoral perspective. Philadelphia: Westminster Press.

Rangaswamy, K. and Bhavani, K. (2008) Impact of disability on the family and needs of families of disabled children, J. Commu. Guid. Res., 25(1), 121130

Rozanski A, Blumenthal JA, Kaplan J. (1999). Impact of psychological factors on the pathogenesis of cardiovascular disease and implications for therapy. Circulation, 99,2192-217

Santrock J.W. (2002). Perkembangan Masa Hidup. Jakarta; Erlangga

Schieve, L. A., Blumberg, S. J., Rice, C., Visser, S.N., and Coleen Boyle. (2007). The Relationship Between Autism and Parent stres. Prediatrics. 119(1), 1144-121. doi: 10.1542/peds.2006-2089Q

Southwick SM, Vythilingam M, Charney DS. (2005) The psychobiology of depression and resilience to stress: Implications for prevention and treatment. Annu Rev Clin Psychol. 1:255-91

Spangenberg, J.J., \& Theron, J.C. (1998). Stress and Coping Strategies in Spouses of Depressed Patients. Journal of Psychology, 133(3), 253-262. doi: 10.1080/00223989909599738

Stansfeld SA, Fuhrer R, Head J, et al. (1997) Work and psychiatric disorder in the whitehall II study. J Psychosom Res 43,73-81. 27.

Syahabuddin. (2010).Hubungan antara Cinta dan Stres dengan Memaafkan pada Suami dan Istri. Yogyakarta: Fakultas Psikologi Universitas Gadjah Mada

Toifur, dan Prawitasari, J. E. (2003). Hubungan antara Status Sosial Ekonomi, Orientasi Religius, dan Dukungan Sosial dengan Burnout pada Guru Sekolah Dasar di Kabupaten Cilacap. Sosiohumanika, 16(3), 511-527.

Uchino BN, Cacioppo JT, Kiecolt Glaser JK. (1996) The relationship between social support and physiological processes: A review with emphasis on underlying mechanisms and implications for health. Psychol Bull $.119: 488-531$. 
Watkins, P. C., Uhder, J., \& Pichinevskiy, S. (2014). Grateful recounting enhances subjective well-being: The importance of grateful processing. The Journal of Positive Psychology, 10(2), 91-98. http://doi.org/10.1080/17439760.2014.927909

Wood, A.M., Froh, J.J., \& Geraghty, A.W. (2010). Gratitude and well-being: A review and theoretical integration. Clinical Psychology Review. 30(7), 890-905. 